\title{
Ti 合金に括けるカソードの電子状態と水素過電圧との関係*
}

\author{
森下政夫**1) \\ 筑田昌宏**2) \\ 芦田喜郎**1) \\ 森 永正彦**3) \\ 湯川夏夫**3) \\ 足立裕彦**4)
}

J. Japan Inst. Metals, Vol. 55, No. 6 (1991), pp. 720-726

Correlation between Electronic States of the Cathodes and Hydrogen Overpotential for Titanium-based Alloys*

\author{
Masao Morishita ${ }^{* * 1)}$, Masahiro Chikuda**2), Yoshio Ashida ${ }^{* * 1)}$, \\ Masahiko Morinaga $^{* * 3)}$, Natsuo Yukawa**3) and Hirohiko Adachi ${ }^{* * 4)}$
}

In order to understand cathodic reactions of Ti-based alloys, local electronic states of the cathode were simulated by a DV-X $\alpha$ cluster method. The basis of the assumption of a local electronic cell model in which the anode was the titanium-matrix region and the cathode was the alloying-element containing region. The molecular orbital calculation shows that two conditions are required for the enhancement of the cathodic reaction in aqueous solutions: (1) the density of states near the Fermi level should be large enough to localize conduction electrons in the cathode region, and (2) the energy of the Fermi level should be high enough to discharge localized electrons so that the hydrogen evolution on the cathode surface proceeds smoothly. This conclusions were supported experimentally by a series of the measurements of polarization curves with Ti-0.1\% (mole fraction) $\mathrm{M}$ alloys ( $\mathrm{M}=\mathrm{W}, \mathrm{Re}, \mathrm{Ir}, \mathrm{Pt}, \mathrm{Au}, \mathrm{Mo}, \mathrm{Ru}, \mathrm{Rh}, \mathrm{Pd}, \mathrm{Ag}, \mathrm{Fe}, \mathrm{Co}, \mathrm{Ni}$ and $\mathrm{Cu}$ ) in $10 \%$ (mass fraction) $\mathrm{H}_{2} \mathrm{SO}_{4}$ solutions. An active cathodic reaction was observed when the alloy contained one of the elements that satisfied the above conditions: $\mathrm{Ir}, \mathrm{Pt}, \mathrm{Ru}, \mathrm{Rh}$ and $\mathrm{Pd}$. The present results indicate that the simulation based on the molecular orbital theory is useful for describing the local electronic states of cathode in aqueous corrosion.

(Received January 7, 1991)

Keywords: titanium-based alloys, molecular orbital method, electronic structure, polarization curves, aqueous corrosion, passivation, hydrogen overpotential

\section{I 。緒言}

著者らは，これまで $\mathrm{Ti}$ 合金の耐食性を電子論に基づき 検討し，アノードの活性溶解速度が，分子軌道計算による 結合次数で整理できることを見出した(1)-(3)．また，カソ ードの局所的電子状態をシミュレーションし(4)，フェルミ 準位に拈ける電子空孔数が多い汪ど電子が局在し易く, フ ェルミ準位の高さが高いほど局在した電子が水素イオンに 放電され易いため, カソード反応が活発化すると推定し た(4)、本報では，前報炕拈るカソードのシミュレーショ ン結果を検討するために，種々の合金元素を添加した 2 元 Ti 合金の分極曲線を硫酸中で測定し, 計算結果 ${ }^{(4)}$ と比 較した。

腐食特性を電子論的に検討したものとして，例えば，純 金属の水素発生速度を表す交換電流密度が仕事関数で整理
できるといら報告がある(5)。また，合金のアノード表面に 和ける酸素の吸着特性が， d バンド中のフェルミ準位直上 の電子空孔と関係するといら報告(6)-(9)など ${ }^{(10)}$ があるが， 合金の電子状態の計算に基づいて腐食特性を検討したもの はない，ただし，本報に打けるカソードの電子状態のシミ ュレーション結果 ${ }^{(4)}$ と分極曲線との比較検討は, 腐食中に 表面組成の変化 ${ }^{(11)}$ が起こらないものとする仮定に基づい ている.

\section{II. 実 験 方 法}

純 Ti 亿合金元素 $M(M=W, R e, I r, P t, A u, M o, R u, R h$, $\mathrm{Pd}, \mathrm{Ag}, \mathrm{Fe}, \mathrm{Co}, \mathrm{Ni}, \mathrm{Cu}$ )を $0.1 \%$ （モル分率）ずつ添加した 合金について分極曲線を測定した。純 Ti は純度 99.6 mass\%のものを，合金元素は純度 99.9 mass\%のものを用 い, $\mathrm{Ar}$ アーク溶解により $\phi 40 \mathrm{~mm} \times 14 \mathrm{~mm}, 100 \mathrm{~g}$ のイン

*1990年 9 月日本金属学会秋期大会に発表 ; Materials Trans., JIM, 32(1991), 264.

**1) (侏)神戸製鋼所材料研究所 (Materials Research Loboratory Kobe Steel, Ltd., Kobe)

**2） (侏)神戸製鋼所材料研究所，現在：(蛛)日輪ゴム工業(Kobe Steel, Ltd., Kobe. Present address: Nichirin Gomu Kogyo, Ltd., Himeji)

**3) 豊橋技術科学大学 (Toyohashi University of Technology, Toyohashi)

**4) 兵庫教育大学 (Hyogo University of Teacher Education, Kato-gun, Hyogo) 
ゴットを溶製した．このインゴットを $1373 \mathrm{~K}$ ，真空中で $86.4 \mathrm{ks}$ の均質化焼鈍し, $1273 \mathrm{~K}$ で $25 \mathrm{~mm} \times 80 \mathrm{~mm} \times 10$ $\mathrm{mm}$ に熱間鍛造, $1123 \mathrm{~K}$ で $25 \mathrm{~mm} \times 90 \mathrm{~mm} \times 7 \mathrm{~mm}$ に熱 間圧延を行った後, 真空中 $1093 \mathrm{~K}, 7.2 \mathrm{ks}$ 保持後炉冷の 熱処理を行った. 熱処理後機械加工により, $15 \mathrm{~mm} \times 15$ $\mathrm{mm} \times 2 \mathrm{~mm}$ の分極試験片を各組成について 4 枚ずつ作製 し，エメリー紙により＃500 番まで表面仕上げした。

分極試験は, ポテンショスタット（日亜計器製作所製, MODEL CW-E2)を記録計(横河電機製，3086X-Y レコー ダー) に接続して行い，腐食液 $10 \%$ (質量分率) $\mathrm{H}_{2} \mathrm{SO}_{4}$ 水溶 液, 温度 $343 \mathrm{~K}$ の条件とした. 試験片の保持方法は, JIS G0579 規格に準じて行い，照合電極に銀塩化銀電極(飽和 $\mathrm{KCl}$ 溶液)を用いて，1.8 ks Ar脱気し，さらに $1.2 \mathrm{ks}$ 保 持して腐食電位が安定化した後, 走査速度 $0.83 \mathrm{mV} / \mathrm{s}$ で, $\mathrm{Ar}$ 雾囲気中でカソード分極，アノード分極を行った．測 定中，腐食液のかきまぜは行わなかった。

\section{III. カソードの電子状態}

まずカソードの局所的電子状態について, 前報(4)の検討 結果を述べる.カソードのシミュレーションは, Fig. 1 に示したモデルについて検討した ${ }^{(4)}$. Ti 低いために, Tiから合金元素に向かって電荷が移行する

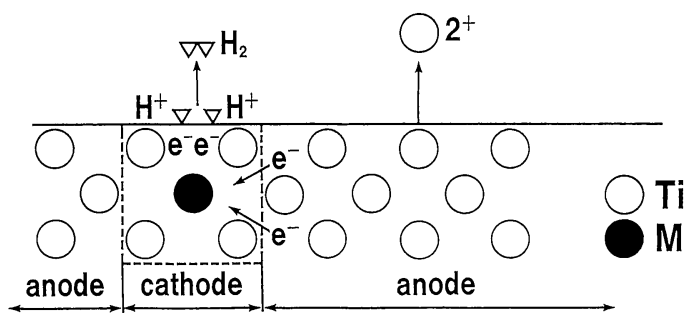

Fig. 1 Schematic model of the electrochemical cell.
と考えられる.すなわち，母金属の Ti からなる基質をア ノードとし, 合金元素 $\mathrm{M}$ とその周囲に配位する $\mathrm{Ti}$ を力 ソードとするモデルである.

水溶液腐食における Ti のアノード反応は一般に次式で 表される(12).

$$
\mathrm{Ti} \rightarrow \mathrm{Ti}^{2+}+2 e^{-}
$$

一方, カソード反応は次式で表される(13).

$$
2 \mathrm{H}^{+}+2 e^{-} \rightarrow \mathrm{H}_{2}
$$

すなわち, Fig. 1 に拈いて, カソード反応が進行するため には,アノードからの伝導電子 $e^{-}$がカソードに移行し， カソードに局在した伝導電子 $e^{-}$が $\mathrm{H}^{+}$に放電される電子 状態でなければならないと考えられる，そこでカソードに $\mathrm{DV}-\mathrm{X} \alpha$ クラスター法を適用し，局所的な電子状態を検討 した(4). Fig. 2 に計算に用いたbcc-Ti の $\mathrm{MTi}_{14}$ クラスタ 一を示した. これは合金元素 $\mathrm{M}$ を中心とするモデルであ る(4).

水素イオンに電子が放電する過程では, フェルミ準位の 電子状態が関係すると推定され(10)(14)(15), カソードが第 6 周期の元素を含む場合には, Fig. 3 のような結果が得ら

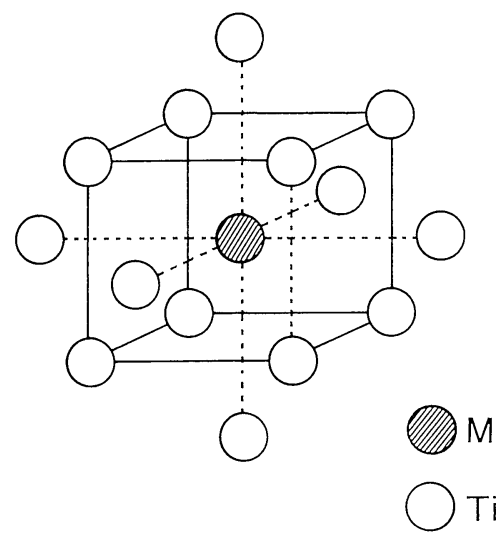

Fig. 2 Cluster model employed in the calculation.

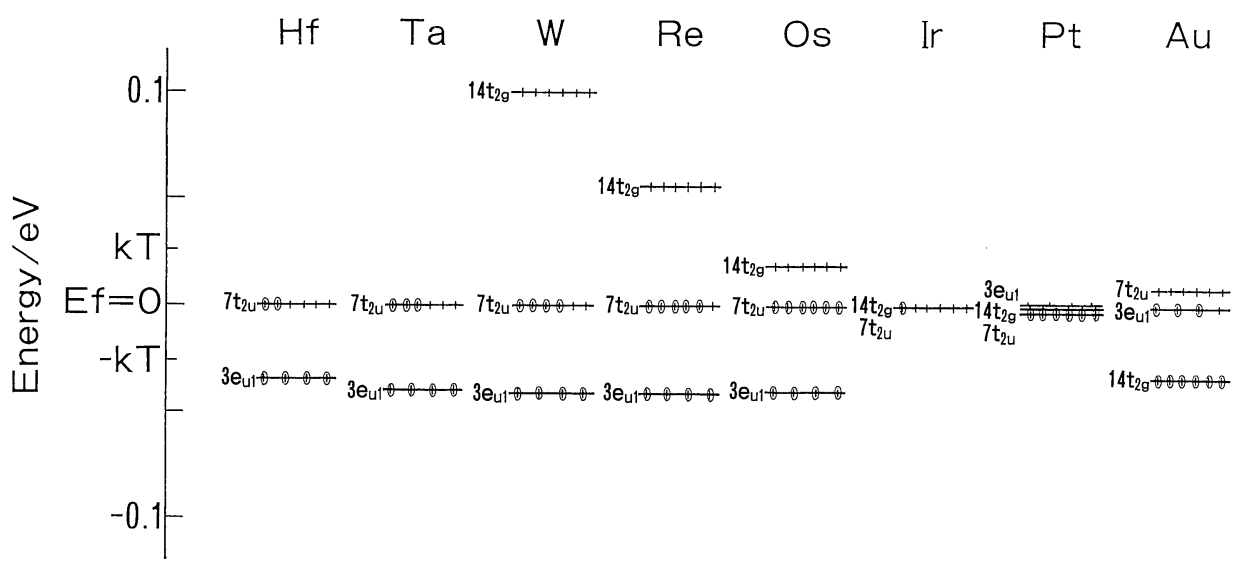

Fig. 3 Energy level structure near the Fermi level of the bcc Ti containing 6th periodic transition metals. A parpendicular bar symbolizes an orbital; when circled, it signifies that the orbital is occupied. 
れた(4). 合金元素が Os, Ir, Pt, Au であるときには, フェ ルミ準位を中心にして，熱ェネルギー $k T\left(2.96 \times 10^{-2}\right.$ $\mathrm{eV})$ の範囲内に $7 \mathrm{t}_{2 \mathrm{u}}, 14 \mathrm{t}_{2 \mathrm{~g}}, 3 \mathrm{eu}_{1}$ の軌道が集中しておゔ, フェルミ準位近傍の状態密度が高くなっている. 状態密度 が高いと，アノードから移行した電子が占有できる空軌道 が多いため, 結果としてカソードでの電子の局在が助長さ れるものと思われる。 したがって, Os, Ir, Pt および $\mathrm{Au}$ を含さカソードでは，電子の局在が大きいことが推定され る. 同様にして, Fig. 4 特よびFig. 5 にそれぞれ示した ように，第 5 周期では $\mathrm{Ru}, \mathrm{Rh}, \mathrm{Pd}, \mathrm{Ag}$ の場合に，第 4 周 期では $\mathrm{Fe}, \mathrm{Co}, \mathrm{Ni}$ の場合に，軌道がフェルミ準位 $E f$ 近傍 に集中し, 状態密度が高く, 電子の局在が大きいことが推 定された.このよらに電子の局在化のみならず, 状態密度 が高いと, Ef 近傍の放電しらる電子数も増えるため, $\mathrm{H}^{+}$ への放電が容易になることも考えられる.

一方，局在した伝導電子はフェルミ準位が高いほど $\mathrm{H}^{+}$ に放電され易いと考えられるので(10)(16)，フェルミ準位の
高さを調べた結果 ${ }^{(4)}$ をig. 6 に示した. 電子を局在させ 易い元素のらち, $\mathrm{Ni}, \mathrm{Ru}, \mathrm{Rh}, \mathrm{Pd}, \mathrm{Ir}, \mathrm{Pt}$ は, フェルミ準位 も高いので, 局在電子を放電させ易いと考えられ，カソー ド反応を活発化させることが推定された(4).

な拉，Ti 合金では，カソード反応を活発にする元素を

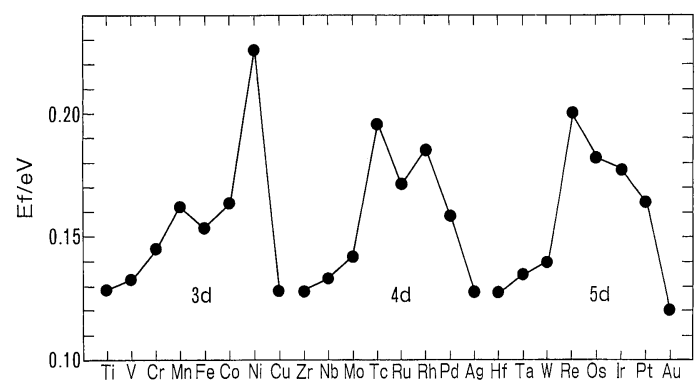

Fig. 6 Fermi levels (Ef) of the bcc Ti containing 4 th, 5 th and 6 th periodic transition metals.

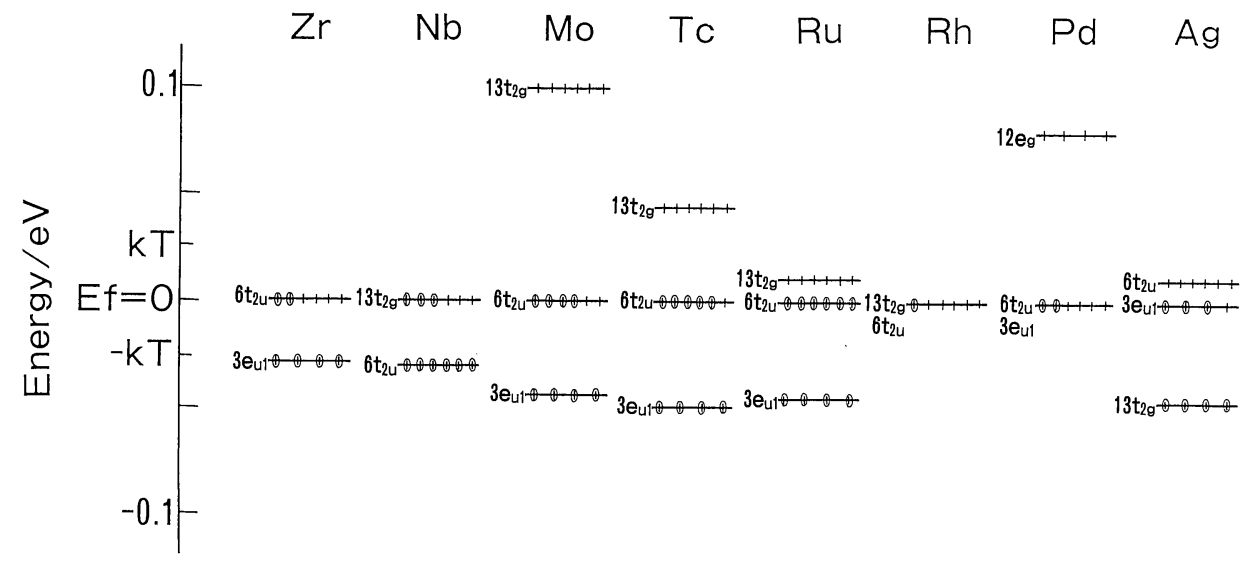

Fig. 4 Energy level structure near the Fermi level of the bcc Ti containing 5th periodic transition metals. A parpendicular bar symbolizes an orbital; when circled, it signifies that the orbital is occupied.

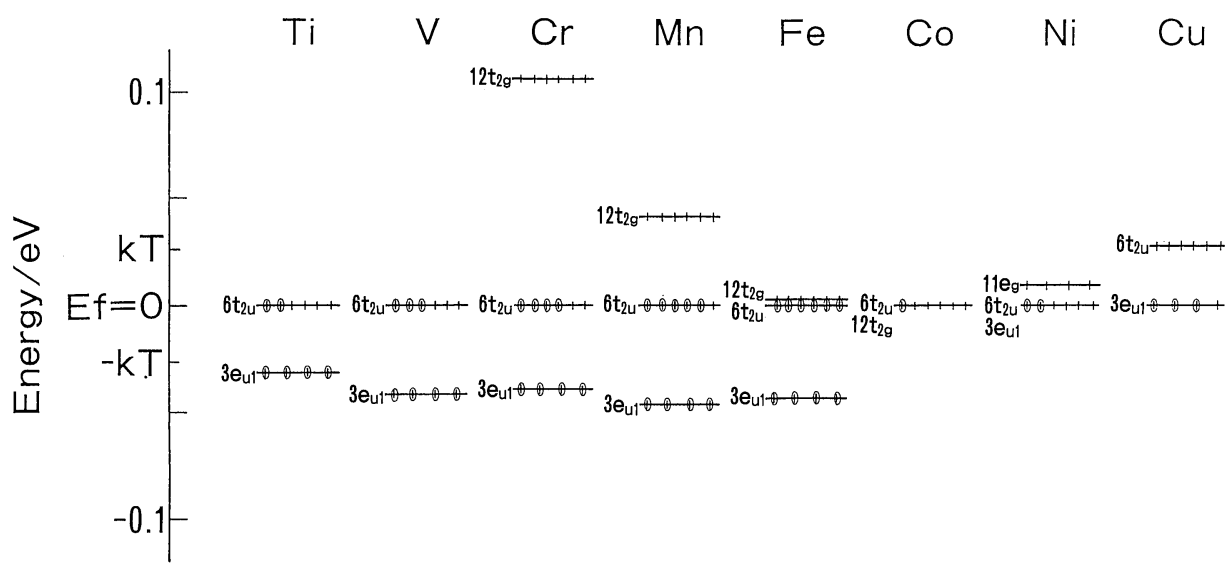

Fig. 5 Energy level structure near the Fermi level of the bcc Ti containing 4th periodic transition metals. A parpendicular bar symbolizes an orbital; when circled, it signifies that the orbital is occupied. 


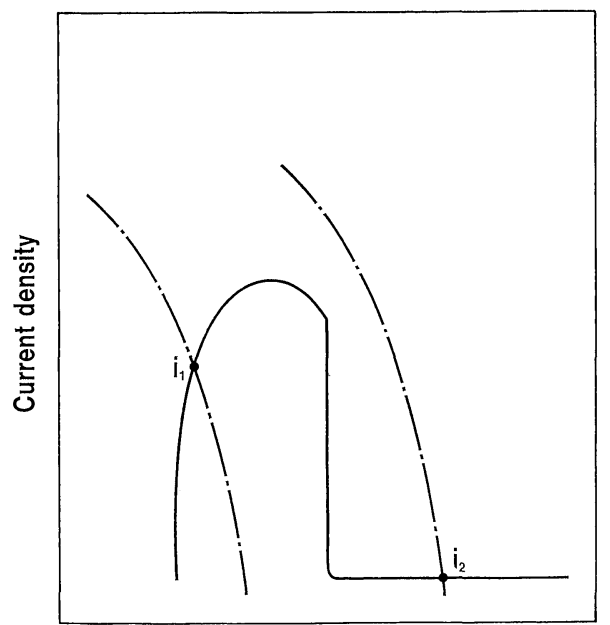

Potential

Fig. 7 Anodic and cathodic polarization curves (schematic).

Anodic polarization curve:

Cathodic polarization curve:

添加すると，不働態化することが知られている(17)(18). こ の機構は Fig. 7 で説明されると考光られる ${ }^{(19)}$. 図中に示 したように，カソード分極曲線とアノード分極曲線との交 点で示される腐食電流密度は，2つの領域に分けられる. すなわち， $i_{1}$ で示される活性溶解領域と， $i_{2}$ で示される不 働態領域である. カソード反応が活発化し，カソード分極 曲線がノーブル側の電位にシフトすると腐食電流密度は, $i_{2}$ で示される不働態領域に移り，耐食性が向上する.

N. 分極測定の結果とカソードシミュレーション結果と の比較

\section{1. 第 6 周期元素}

カソードが Ni, Ru, Rh, Pd, Ir, Pt を含む場合には，電子 が局在し易く，局在した電子が放電され易いために，カソ 一ド反応が活発化することが推定された。このことを明ら かにするために，Ti-0.1\% (モル分率) M 合金 $(\mathrm{M}=\mathrm{W}, \mathrm{Re}$, $\mathrm{Ir}, \mathrm{Pt}, \mathrm{Au}$ (第 6 周期), Mo, Ru, Rh, Pd, $\mathrm{Ag}$ (第 5 周期), $\mathrm{Fe}, \mathrm{Co}, \mathrm{Ni}, \mathrm{Cu}$ (第 4 周期))について, 10\%(質量分率) $\mathrm{H}_{2} \mathrm{SO}_{4}$ 中 $343 \mathrm{~K}$ で分極曲線を測定した. まず，Fig. 8 に， 第 6 周期の合金元素を添加した場合の分極曲線を示した. Ir 执よび Pt を添加した合金については，水素過電圧が小 さく, カソード分極曲線は貴な電位領域にシフトして, 結 果としてアノード分極曲線は不働態化した. Ir, Pt を含む 合金はフェルミ準位近傍の状態密度が高く, かつフェルミ 準位そのものも高いことから ${ }^{(4)}$ カソード反応が活発になる と推定される.

$\operatorname{Re}$ を添加した合金の水素過電圧は大きく，カソード分 極曲線は卑な電位領域に現れた．Reを含むカソードの場

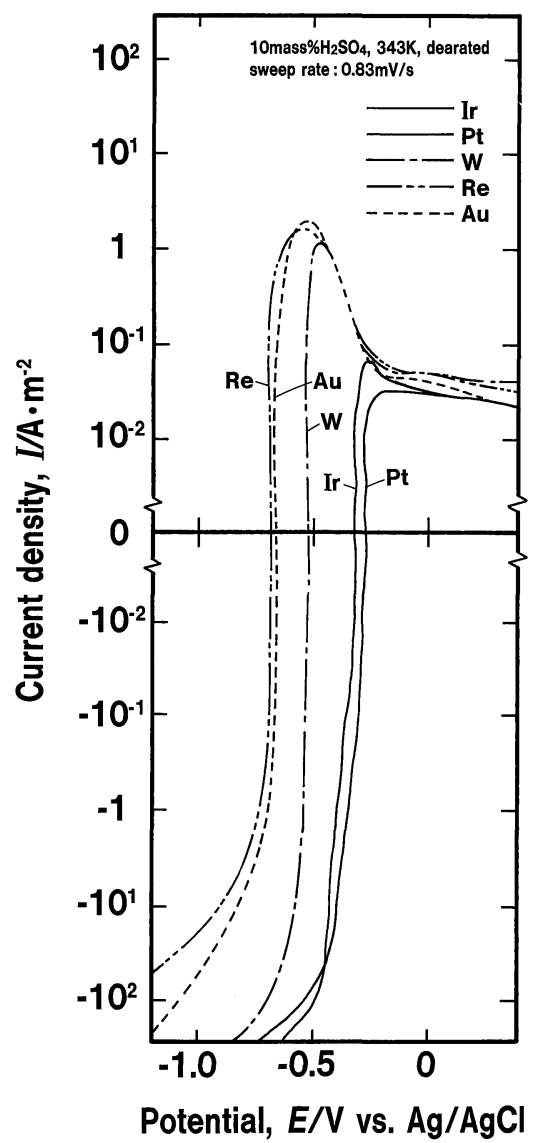

Fig. 8 Polarization curves for Ti-0.1 at $\% \mathrm{~W}, \mathrm{Re}, \mathrm{Ir}$, $\mathrm{Pt}$ and $\mathrm{Au}$ alloys measured in $10 \% \mathrm{H}_{2} \mathrm{SO}_{4}$ at $343 \mathrm{~K}$.

合, フェルミ準位は高いが，状態密度が小さいために，電 子の局在が十分ではなく, カソード反応が不活性になると 推定される(4).

$\mathrm{Au}$ を添加した合金の水素過電圧も大きく，カソード分 極曲線は卑な電位領域に現れた。A を添加した場合, 状 態密度が大きく電子は局在し易いが，フェルミ準位が低い ために，局在した電子が放電されにくいと考えられる.

$\mathrm{W}$ を添加した合金のカソード分極曲線は，Re招よび $\mathrm{Au}$ と比較すると貴な電位領域にシフトした．これは，W を含むカソードは, 比較的状態密度が高く, また, フェル ミ準位も比較的に高いためであると考えられる。

\section{2. 第 5 周期元素}

Fig. 9 に，第 5 周期の合金元素を添加した場合の分極 曲線を示した． Ru, Rh 拈よび Pdを含む合金については， 水素過電圧が小さく，カソード分極曲線は貴な電位領域に シフトして, 結果としてアノード分極曲線は不働態化し た。この実験結果は， $\mathrm{Ru}, \mathrm{Rh}$ 和よび $\mathrm{Pd}$ を含むカソード は, フェルミ準位近傍の状態密度が高く，またフェルミ準 位も高いためカソード反応が活発であると推定したシミュ 


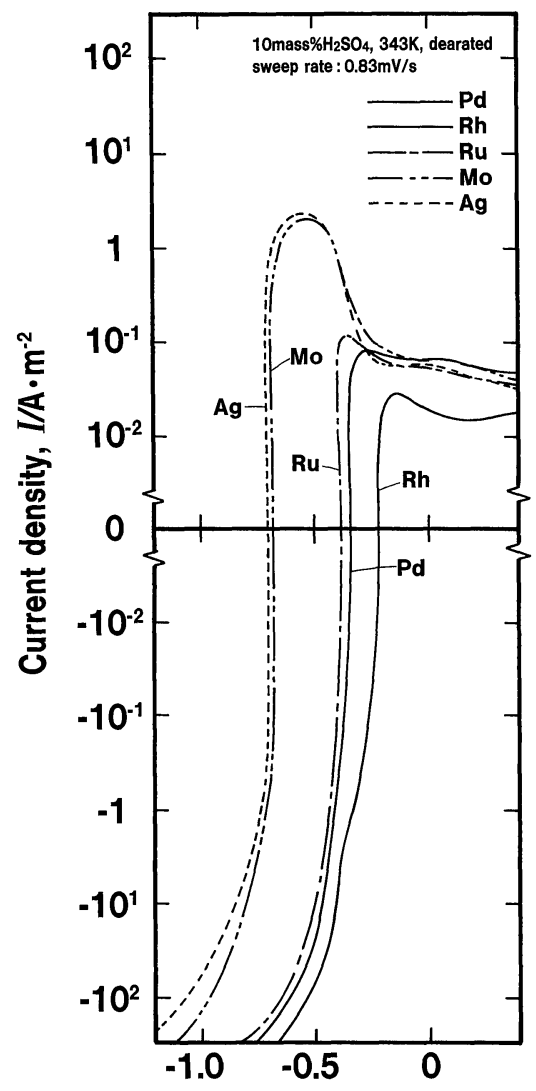

Potential, $\mathrm{E} / \mathrm{V}$ vs. $\mathrm{Ag} / \mathrm{AgCl}$

Fig. 9 Polarization curves for Ti-0.1 at\% Mo, Ru, $\mathrm{Rh}, \mathrm{Pd}$ and $\mathrm{Ag}$ alloys measured in $10 \% \mathrm{H}_{2} \mathrm{SO}_{4}$ at 343 $\mathrm{K}$.

レーション結果によく合致するものである.

次に Ag を添加した合金については，水素過電圧が大き く，カソード分極曲線は卑な電位領域に現れた。 $\mathrm{Ag}$ を添 加した場合，フェルミ準位近傍の状態密度は高いが，フェ ルミ準位が低いため， $\mathrm{H}^{+}$に放電しにくく，カソード反応 が起こりにくいと考えられる.

Mo を添加した合金については，Agの場合よりも水素 過電圧がわずかながら小さかった. この原因の一つとして, Mo の場合, $\mathrm{Ag}$ と比較するとフェルミ準位が高いためで あると考劣らる。

\section{3. 第 4 周期元素}

Fig. 10 に，第 4 周期の合金元素を添加した場合の分極 曲線を示した. Niを添加した場合の水素過電圧は, $\mathrm{Fe}$, $\mathrm{Co}, \mathrm{Cu}$ を添加した場合よりも小さかった．このことは, $\mathrm{Fe}, \mathrm{Co}, \mathrm{Cu}$ を添加した場合よりも, Ni を添加した場合に は,フェルミ準位が高いため，カソード反応が活発になる ものと考觉らる.

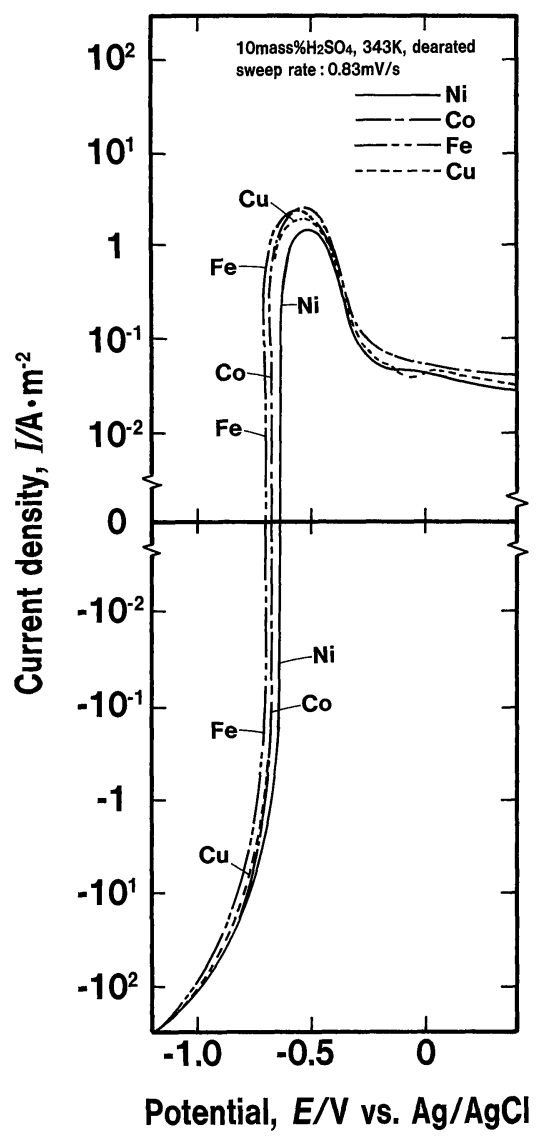

Fig. 10 Polarization curves for Ti- 0.1 at $\% \mathrm{Fe}, \mathrm{Co}, \mathrm{Ni}$ and $\mathrm{Cu}$ alloys measured in $10 \% \mathrm{H}_{2} \mathrm{SO}_{4}$ at $343 \mathrm{~K}$.

\section{V. 考察}

以上述べた一連の分極曲線の測定により, カソードの局 所的電子状態を分子軌道計算でシミュレーションすること は，カソード反応を理解する上で有効であると思われた. しかしながら，本計算には，いくつかの問題が残ってい る.例えば計算結果では, Ni を含む合金のカソード反応 は, Ru, Rh, Pd, Ir, Ptを含む合金と同じ程度に活発であ るといらことが予測されたが，Fig. 10 に示したように分 極測定の結果では，Ni を含も合金のカソード分極曲線は， $\mathrm{Ru}, \mathrm{Rh}, \mathrm{Pd}, \mathrm{Ir}, \mathrm{Pt}$ を含む合金ほどには, 貴電位側へのシ フトがみられなかった.さらに, 計算結果では, Moを含 む合金のカソード反応は $\mathrm{W}$ と同じ程度に起こるというこ とが予測されたが，分極測定の結果では，Wの方が Mo よりもカソード反応が活発であった. これらの計算と分極 測定結果の差異は, 今のところ不明である.

また，合金の組織もカソード反応に影響を及ぼすかもし れない, 本研究では, 計算を簡略化するために, カソード 


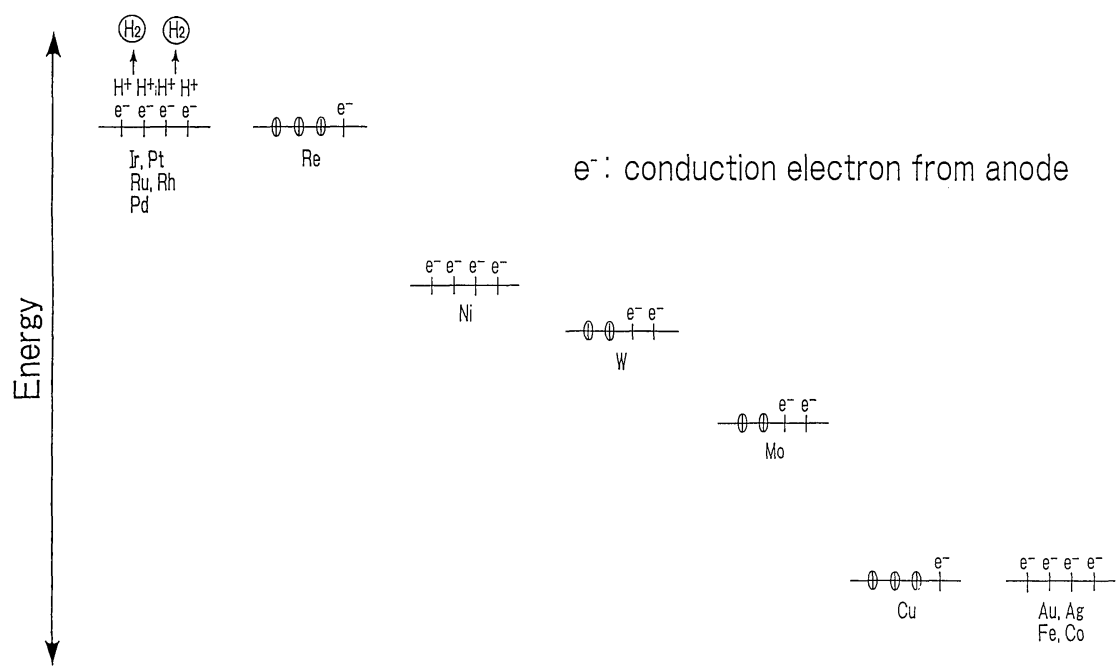

Fig. 11 Schematic model of cathodic reaction.

がbccの $\beta$ 相のみからなると仮定した。 しかしながら， 分極測定を行った合金中には， $\beta$ 相以外に， $\mathrm{Ti}_{3} \mathrm{Ir}, \mathrm{TiFe}$, $\mathrm{Ti}_{2} \mathrm{Co}$ 相などの金属間化合物の析出も認められた. これら の金属間化合物相の析出は少量でもカソード反応に影響を 及ぼすと推定されるので，析出した金属間化合物の腐食に 及ぼす影響を検討する必要がある.これらの相の電子構造 の計算を行い，分極曲線と比較検討することがさらに必要 であるものと思われる.

本研究結果を Fig. 11 によとめた. カソードが Ru, Rh, $\mathrm{Pd}, \mathrm{Ir}, \mathrm{Pt}$ の各元素を含む場合には，フェルミ準位近傍の 状態密度が高く, またフェルミ準位も高いために, カソー ド反応が活発に起こる. カソードが Re を含む場合には， 状態密度が低く, 電子の局在化が不十分であるために，力 ソード反応が活性ではない。一方, カソードが Fe, Co, $\mathrm{Ag}, \mathrm{Au}$ を含む場合には, 状態密度は高いがフェルミ準位 が低いために，カソード反応が活発ではない、また，カソ ードが Cuを含む場合には, 状態密度が低く,フェルミ準 位も低いために，カソード反応が起こりにくい.さらに， カソードが $\mathrm{Ni}, \mathrm{Mo}, \mathrm{W}$ を含む場合には, 比較的状態密度 が高く,フェルミ準位も高く, 分極測定の結果もカソード 反応が比較的活発であることを示したので, 図中の位置に モデル化できるものと考えた.

最後に本研究の結果を純金属のデータ(20) と比較すると, 興味深いことに純金属の水素発生の速度を示す交換電流密 度は, 本研究の結果と類似して, 原子番号とともに周期的 に変化している(20). 例えば，第 5 周期の純金属では, $\mathrm{Ru}, \mathrm{Rh}, \mathrm{Pd}$ の交換電流密度は大きく, $\mathrm{Ag}$ の交換電流密度 は小さくなって扣り ${ }^{(20)}$, 本研究の結果と類似しているこ とが認められた．この問題については，純金属の電子構造 を体系的に理解し，さらに検討することが必要であると考 えられる.な扣，前報(4)では，カソードのフェルミ準位に
扣ける電子空孔数のみに注目して, 電子の局在化を考察し た. しかし, 金属の場合, 電子空孔という概念を内包して いるフェルミ準位を中心とした $k T$ 範囲内の状態密度の方 がより一般的であり，分極測定の結果もよく理解できると いらことがわかった。

\section{V. 結 言}

$\mathrm{Ti}$ 合金のカソード反応を局部電池モデルによって電子 論に基づき検討した．Ti は電気陰性度が低いために，Ti から合金元素に向かって電荷の移行が生じる. その結果, マトリックスの Ti からなる領域がアノードとなり，合金 元素を含む領域がカソードとなる.

カソードの分子軌道計算の結果は, カソード反応を促進

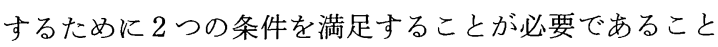
を示唆している.すなわち，第 1 の条件として，カソー ドの領域に電子を局在させるために，フェルミ準位近傍の 状態密度が高いこと, 第 2 に, カソードの表面で水素イ オンに局在した電子を放電させるために，フェルミ準位が 高いことである.

一連の Ti-0.1\%(モル分率) $\mathrm{M}$ 合金 $(\mathrm{M}=\mathrm{Fe}, \mathrm{Co}, \mathrm{Ni}$, $\mathrm{Cu}, \mathrm{Mo}, \mathrm{Ru}, \mathrm{Rh}, \mathrm{Pd}, \mathrm{Ag}, \mathrm{W}, \mathrm{Re}, \mathrm{Ir}, \mathrm{Pt}, \mathrm{Au})$ の分極測定の 結果は，上の結論を支持している．2つの条件を満足する $\mathrm{Ru}, \mathrm{Rh}, \mathrm{Pd}, \mathrm{Ir}$ 㧊よび Pt を含む合金では活発なカソード 反応がみられた。一方， 2 条件を満足できない $\mathrm{Fe}, \mathrm{Co}$, $\mathrm{Cu}, \mathrm{Ag}$ 执よび $\mathrm{Au}$ を含む合金ではカソード反応が活性で ないといらことがわかった。

以上のよらに，分子軌道理論に基づくシミュレーション は水溶液腐食に拉けるカソードの電子状態を検討する上で 有効であることが判明した。 


\section{文献}

（1）森下政夫, 河合伸泰, 吉川克之, 森永正彦, 湯川 夏夫，足立裕彦：日本金属学会誌，54(1990), 568 .

（2）森下政夫，筑田昌宏，声田喜郎，森永正彦，湯川 夏夫，足立裕彦：鉄と鋼, $76(1990), 2175$.

( 3 ) M. Morishita, M. Chikuda, Y. Asida, M. Morinaga, N. Yukawa and H. Adachi: ISIJ. Int., to be published, 31 (1991), No.8.

（4）森下政夫, 筑田昌宏, 声田喜郎, 森永正彦, 湯川 夏夫，足立裕彦：日本金属学会誌，54(1990), 1369.

（5）喜多英明, 魚崎浩平: 電気化学の基礎, 技報堂, (1983), 242.

(6) H. H. Uhlig: Trans Electrochem. Soc., 85(1944), 307.

( 7 ) H. H. Uhlig and J. Walf: Trans. AIME, 135(1959), 494.

( 8 ) H. H. Uhlig: Z. Elektrochem., 62 (1958), 700.

(9) T. Heuman: Z. Elektrochem., 55(1959), 287.
（10）佐藤教男：防食技術，39(1990)，495.

(11) H. Sato, K. Shimogori, H. Tomari and A. Aoki: Proc. Conf. on Titanium and Titanium Alloys, Moscow, Edt. by J. C. Williams and A. F. Belov, Plenum Press, AIME and ASM,(1982), 881.

(12) H. H. Uhlig : 腐食反応とその制御, 岡本 剛監修, 松田誠吾, 松島 嚴共訳, 産業図書, (1979), 345.

（13）佐藤教男 : 材料科学, $23(1987), 213$.

(14) K. Fukui, T. Yonezawa, C. Nagata and H. Shingu: J. Chem. Phys., 22(1954), 1433.

(15) K. Fukui, T. Yonezawa and C. Nagata: J. Chem. Phys., 27(1957), 1247.

（16）米澤貞次郎, 永田親義, 加藤博文, 今村 栓, 諸熊 奎治：量子化学入門 (上), 化学同人, (1988), 147.

(17) M. Stern and H. Wissenberg: J. Electrochem. Soc., 106(1959), 755.

(18) M. Stern and H. Wissenberg: J. Electrochem. Soc., 106(1959), 759.

(19) N. D. Green: Corrosion, 18(1962), 136.

（20）喜多英明, 魚崎浩平: 電気化学の基礎, 技報堂, (1983), 241. 